\title{
Baker urges concentration of research in fewer universities
}

\section{London}

Mr Kenneth Baker, the British Secretary of State for Education and Science, while still preoccupied with his running battle with schoolteachers over pay, is planning also to turn his attention to the administration of those parts of the research enterprise within his charge - academic research and the institutes of the four science-based research councils.

Further reorganization of the research council system is, however, unlikely. $\mathrm{Mr}$ Baker seems content with the present division of responsibility between the research councils, but is anxious that their work should be more pointed. One focus of concern is the extent to which research council funds are committed in advance by long-term obligations.

$\mathrm{Mr}$ Baker is less certain of the constitution of the Advisory Board for the Research Councils (ABRC), which gives him advice on the partition of the annual science budget among the research councils. One possibility is that the most interested parties, the research councils themselves, might not be directly represented on the council. Another is that the ABRC may be better provided with people able to monitor changing patterns of research at British institutions. Much will no doubt depend on the views of the ABRC chairman Sir David Phillips, of whom Mr Baker seems thoroughly to approve.

On the university front, the drive towards the concentration of research in a smaller number of universities or univerity departments, which has already influenced the allocations of funds to individual universities in the present academic

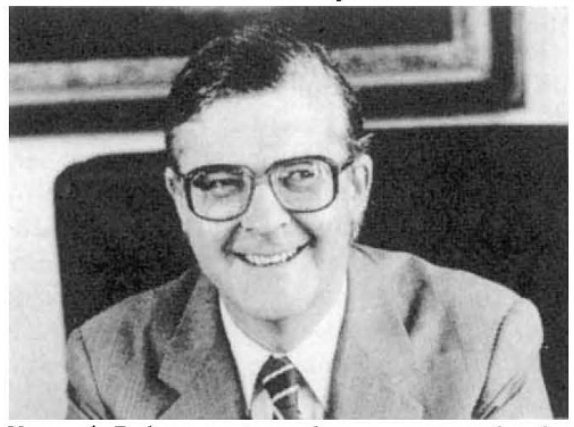

Kenneth Baker sees tax reforms as a cure for the 'brain drain'.

year and, in a letter to universities last month, for the academic year beginning in August, will be encouraged. Last week, $\mathrm{Mr}$ Baker was even wondering aloud whether "some universities should become teaching institutions", with no substantial research activity.

Meanwhile, Mr Baker acknowledges that something must be done about the rate at which British scientists are being tempted abroad by better working condi- tions and, particularly, by better salaries. In the long run, he believes, the longstanding annual loss of something like 1,000 people a year, which may recently have increased, may require that attention should be given to radical changes in British tax arrangements to make them more competitive with those now in force in the United States under the provisions of last year's Tax Reform Act.

In the world of practical politics, however, Mr Baker says he will be looking at a variety of other measures. He hopes that the Royal Society's study of the loss of skilled people from Britain, due to be completed soon, will have some practical suggestions to make. He also wonders whether it may be necessary for some employers to take a leaf out of another US book, and to look to countries such as India for replacements for lost British academics. John Maddox

\section{IMAGE UNAVAILABLE FOR COPYRIGHT REASONS}

Tokyo

ONE of the first images taken by Japan's marine observation satellite Momo, launched on 19 February. This non-corrected false-colour image, taken by the satellite's multi-spectral electronic self-scanning radiometer on 23 February at about 10.50 a.m., is of Ohmura Bay off Kyushu (Nagasaki airport is visible in the bay linked to the mainland by a causeway). Blue and green represent bands 1 and 2 in the visible spectrum $(0.51-0.59 \mu \mathrm{m}$ and $0.61-0.69$ $\mu \mathrm{m}$, respectively), and red is band 4 in the near infrared $(0.72-0.80 \mu \mathrm{m})$. The photograph spans about $20 \mathrm{~km}$ east to west and $36 \mathrm{~km}$ north to south.

\section{New civil service pay deal betters par}

\section{London}

High fliers in the British scientific civil service specializing in disciplines much in demand will reap substantial financial rewards in the next few years from the introduction of a radical new pay structure. As part of an offer by the British Treasury to the Institution of Professional Civil Servants (IPCS), there will be guaranteed increases of pay for all staff in the next two years, with the promise of further increases for people in fields with "recruitment and retention problems".

The pay offer covers IPCS staff working in the public service, not only in the civil service. IPCS is the negotiating body for some 60,000 scientists and technologists, many working for quasi-autonomous organizations such as the UK Atomic Energy Authority.

Those concerned will receive a pay increase on 1 April amounting to the percentage increase of the Retail Price Index in the year to the end of last month, expected to be about 3.9 per cent. There will be further pay increases in September and next April making a total estimated at 15 per cent. The new merit increases will also be effective from September.

One striking feature of the pay award is that it appears to breach the government's position that pay increases in the public sector should not exceed the rate of inflation. But the new structure has also been designed to reward individual performance and in such a way that merit awards are not uniformly spread over large diverse groups of scientific workers.

According to the Treasury, the intention is that the rewards of members of the scientific civil service should be determined by the performance of small, not large, groups in which they work and even on an individual basis, taking account of the skills employed as well as of "conditions in different parts of the country". The last of these provisions is in line with the British government's wish, put forcefully to a meeting of the National Economic Development Council last week, that pay bargaining should take account of the variation of living costs between different parts of Britain.

The scheme proposed for the scientific civil service aims to reward personal performance in ways that match those obtainable in industry. An essential part of the proposals is that there should be more effective individual job evaluation. The proposed deal, which will be effective until August 1989, will be discussed at a special conference of IPCS on 8 April.

Bill Johnstone 